\title{
American College of Radiology and Society of Nuclear Medicine and Molecular Imaging Joint Credentialing Statement for PET/MR Imaging: Brain
}

\author{
Hossein Jadvar ${ }^{1}$, Rathan M. Subramaniam ${ }^{2}$, Claudia G. Berman ${ }^{3}$, Fernando Boada ${ }^{4}$, Patrick M. Colletti ${ }^{5}$, \\ Alexander R. Guimaraes ${ }^{6}$, Jonathan McConathy ${ }^{7}$, Carolyn C. Meltzer ${ }^{8}$, Richard B. Noto ${ }^{9}$, Alan B. Packard ${ }^{10}$, \\ Eric M. Rohren ${ }^{11}$, and M. Elizabeth Oates ${ }^{12}$ \\ ${ }^{1}$ University of Southern California, Los Angeles, California; ${ }^{2}$ Johns Hopkins University, Baltimore, Maryland; ${ }^{3}$ Moffitt Cancer \\ Center, Tampa, Florida; ${ }^{4}$ New York University, New York, New York; ${ }^{5}$ University of Southern California, Los Angeles, California; \\ ${ }^{6}$ Massachusetts General Hospital, Boston, Massachusetts; ${ }^{7}$ Washington University, St. Louis, Missouri; ${ }^{8}$ Emory University, Atlanta, \\ Georgia; ${ }^{9}$ Brown University, Providence, Rhode Island; ${ }^{10}$ Boston Children's Hospital, Boston, Massachusetts; ${ }^{11}$ M.D. Anderson \\ Cancer Center, Houston, Texas; and ${ }^{12}$ University of Kentucky, Lexington, Kentucky
}

$\mathbf{F}$ the Joint Commission on Accreditation of Healthcare Organizations and, previous to that, the Joint Commission on Accreditation of Hospitals, is a United States-based nonprofit organization that accredits more than 20,000 health care organizations and programs in the United States. The Joint Commission requires that there be a credentialing system for delineating and granting privileges for every hospital physician. The Joint Commission does not specify those qualifications. Privileges are generally practicespecific and are not usually transferable from hospital to hospital. The granting of clinical privileges cannot and should not depend on a single criterion such as board certification or membership in a particular specialty society; other options, such as documented evidence of requisite training, relevant experience, judgment skills, and demonstrated current competence, should be available. It is the final responsibility of the hospital medical staff and hospital governing board to ensure that a physician meets a reasonable standard of competency.

$\mathrm{PET} / \mathrm{MR}$ imaging is an emerging complex hybrid imaging modality recently introduced into clinical practice (1-3). In June 2013, the American College of Radiology (ACR) and the Society of Nuclear Medicine and Molecular Imaging (SNMMI) charged a joint task force with developing a credentialing statement for physicians responsible for the oversight and interpretation of PET/ MR imaging examinations. The task force has prepared this joint statement related to brain PET/MR imaging as the first in a planned series of credentialing statements covering all organ systems and clinical applications.

This joint statement is intended to guide credentialing bodies that privilege physicians to oversee, supervise, and interpret brain PET/MR imaging for patient care in the United States.

Received Jan. 30, 2015; revision accepted Feb. 4, 2015.

For correspondence or reprints contact: Hossein Jadvar, University of Southern California, 2250 Alcazar St., CSC 102, Los Angeles, CA 90033.

E-mail: jadvar@med.usc.edu.

Published online Mar. 5, 2015.

COPYRIGHT (C) 2015 by the Society of Nuclear Medicine and Molecular Imaging, Inc.

DOI: $10.2967 /$ jnumed.115.155218

\section{DEFINITIONS}

For the purposes of this statement, the following definitions apply: Radiopharmaceutical: A radioactive compound administered to patients for use in diagnosis and therapy.

PET: A medical imaging technology that uses positron-emitting radiopharmaceuticals. The PET scanner detects the high-energy annihilation photon pairs and extrapolates the location of the original positron-emitting atom to create tomographic images of its biodistribution within the body.

MR imaging: A medical imaging technology that uses highstrength magnetic fields to create high-contrast tomographic images. MR imaging techniques primarily delineate anatomy, but special MR sequences such as functional MR imaging, MR spectroscopy, and perfusion- and diffusion-weighted MR imaging provide functional information.

PET/MR imaging: A complex hybrid medical imaging technology that incorporates PET and MR imaging into a single device. Such an imaging system allows either sequential acquisition (i.e., tandem back-to-back design) or simultaneous acquisition (i.e., PET insert in MR imaging gantry or integrated PET/MR imaging design). In either hybrid system, the goal is combined PET and MR image data for exact coregistration.

\section{APPLICATIONS FOR BRAIN PET/MR IMAGING}

The following are examples of potential clinical or research applications for PET/MR imaging of the brain (1-5): neoplastic conditions or masses or masslike conditions of brain parenchyma, meninges, or cranium, primary or metastatic; cerebrovascular processes such as stroke, ischemia, or defining ischemic penumbra; seizure disorders; metabolic, inflammatory, and autoimmune disorders such as demyelination; neurodegenerative disorders such as dementia (Alzheimer disease, frontotemporal dementia, Lewy body dementia, vascular dementia) and movement disorders such as Parkinson disease; and neuropsychiatric disorders such as depression, addiction, and schizophrenia. 


\section{RESPONSIBILITIES OF PHYSICIANS}

A physician must be responsible for all aspects of the brain PET/MR imaging examination, such as reviewing indications for the examination, prescribing the PET radiopharmaceutical and its dose, specifying the MR imaging pulse sequences to be performed, prescribing the use and dose of MR imaging contrast agents, confirming the quality of the images appropriate for interpretation, interpreting the images, generating final reports, and ensuring patient and personnel safety. A prescriber of radiopharmaceuticals must either be or work under a U.S. Nuclear Regulatory Commission authorized user of radioactive materials and comply with state regulations, or hold the Canadianequivalent authorization.

With regard to supervision and interpretation of brain PET/MR imaging, physicians may best participate in their practice according to their special interests and qualifications in nuclear medicine and molecular imaging, neuroradiology, or related practice paradigms. It is recognized that variations in the local regulatory requirements for practices and individual-physician qualifications may of necessity dictate site-specific practice patterns. For example, in certain clinical settings, it may be beneficial for 2 physicians to interpret brain PET/MR imaging examinations together, with one primarily interpreting the PET component and other primarily interpreting the MR imaging component. Nevertheless, the interpreters should meet the credentialing criteria for the modality for which they are providing a primary interpretation. The 2 physicians must reach consensus regarding the final interpretation of the combined PET/ MR imaging findings to issue a joint PET/MR imaging report (1 billing physician of record) or 2 separate correlative PET/MR imaging reports.

Simple numeric criteria are not an optimal measure of competency. Documentation of competency by the use of objective, outcome-based tools related to clinical experience is preferable. The criteria detailed in Table 1 may be used for guidance.

The rigorous recommendations for PET/MR imaging practice set forth in this document have been developed in consideration of the complex nature of this emerging hybrid modality and with reference to published practice parameters, procedure guidelines, and credentialing statements (6-11).

The practice of PET/MR imaging requires a solid knowledge base of PET techniques and MR imaging techniques. Although the ultimate goal is mastery of simultaneously acquired brain PET/ MR imaging examinations, the physician's education, training, and experience should encompass dedicated brain PET, brain PET/CT, and dedicated brain MR imaging. Fundamentals include familiarity with technical parameters (protocols, contrast agents, sequences, processing) as well as biologic and clinical parameters (anatomy, physiology, normal variants, disease states).

The recommendations set forth include, first, a first-hand review and supervised interpretation of hybrid PET/MR imaging or separately acquired PET and MR imaging examinations of the brain and, second, didactic educational hours in the basic science and clinical applications of each modality.

\section{QUALIFICATIONS OF PHYSICIANS RESPONSIBLE FOR BRAIN PET/MR IMAGING_INITIAL COMPETENCY}

All physicians assuming responsibility for independent practice of PET/MR imaging of the brain should meet at least 1 of the categories for initial competency criteria outlined in Table 1.

\section{Clinical Experience/Supervised Interpretations}

In each modality, cases must include broad representation of types of examinations, available radiopharmaceuticals, contrast agents, and indications encountered in clinical practice. Cases presented in specifically designed society- or organizationapproved case-based conferences or courses, live or online, are acceptable. Documented cases with direct participation during residency or fellowship may be counted. Of note, hybrid brain PET/MR imaging cases may be counted in each appropriate category (i.e., they may be counted twice) to fulfill the recommendation.

For amyloid imaging, there are industry-sponsored training programs (12-13). In certain specialized clinical settings (e.g., practices limited to pediatrics), the proposed criteria for amyloid PET may be waived.

\section{Didactic Education Hours}

Didactic education should supplement case-based conferences used to achieve the number of supervised interpretations and should include PET physics plus MR imaging physics, brain PET radiopharmaceuticals plus MR imaging contrast agents, safe handling of radioactive materials plus MR imaging safety, and PET plus MR imaging protocols (sequences). Hours spent during residency or fellowship are acceptable.

\section{QUALIFICATIONS OF PHYSICIANS RESPONSIBLE FOR BRAIN PET/MR IMAGING-CONTINUING COMPETENCY}

All physicians assuming responsibility for independent practice of PET/MR imaging of the brain should meet at least 1 of the categories for continuing competency criteria outlined in Table 1.

\section{Clinical Experience/Supervised Interpretations}

Cases must comprise a broad representation of types of examinations, available radiopharmaceuticals, contrast agents, and indications encountered in clinical practice, including cases presented in specifically designed society- or organization-approved case-based conferences. Direct participation in clinical cases should include involvement in all aspects of examination from protocoling through interpretation; effective participation cannot be achieved by more than 3 individuals per case. Objective documentation of direct participation should be kept by each physician.

\section{Didactic Education Hours}

Didactic education should include at least $50 \%$ of the required hours in dedicated brain PET/MR imaging, with the remainder in brain PET or brain MR imaging, or at least $50 \%$ of required hours in brain PET and at least $50 \%$ in brain MR imaging.

\section{APPROVAL}

This credentialing statement was approved by the ACR board of chancellors and by the SNMMI board of directors in January 2015.

\section{JOINT COMMISSION PARTICIPANTS}

The SNMMI participants include Hossein Jadvar, Claudia G. Berman, Patrick M. Colletti, Richard B. Noto, Alan B. Packard, and Eric M. Rohren. The ACR participants include Rathan M. Subramaniam, Fernando Boada, Alexander R. Guimaraes, 
TABLE 1

Initial and Continuing Competency Criteria for Credentialing Physicians for Independent Practice: PET/MR Imaging of Brain

\begin{tabular}{|c|c|c|c|c|}
\hline \multirow[b]{2}{*}{$\begin{array}{l}\text { Training/ } \\
\text { certification }\end{array}$} & \multicolumn{2}{|c|}{ Initial competency criteria } & \multicolumn{2}{|c|}{ Continuing competency criteria } \\
\hline & $\begin{array}{l}\text { No. of supervised } \\
\text { interpretations in } \\
\text { past } 36 \mathrm{mo}\end{array}$ & $\begin{array}{l}\text { No. of didactic education } \\
\text { hours in past } 36 \text { mo }\end{array}$ & $\begin{array}{l}\text { No. of supervised } \\
\text { interpretations in past } 36 \mathrm{mo}\end{array}$ & $\begin{array}{l}\text { No. of didactic education } \\
\text { hours in past } 36 \text { mo }\end{array}$ \\
\hline \multirow{2}{*}{$\begin{array}{l}\text { ABR-DR, ABR-DR- } \\
\text { NR, ABR-DR } \\
\text { with } \\
\text { neuroradiology } \\
\text { CAQ, ABNM, } \\
\text { AOBR, RCPSC } \\
\text { or Collège des } \\
\text { Médecins du } \\
\text { Québec } \\
\text { certification, or } \\
\text { board eligibility } \\
\text { within } 2 \text { y of } \\
\text { completing } \\
\text { residency/ } \\
\text { fellowship }\end{array}$} & $\begin{array}{l}30 \text { brain }{ }^{18} \mathrm{~F}-\mathrm{FDG} \text { PET } \\
\text { examinations; vendor- } \\
\text { provided training for } \\
\text { amyloid PET } \\
\text { examinations if } \\
\text { applicable }\end{array}$ & $\begin{array}{l}\text { PET: } 20 \mathrm{~h} ; 3 \mathrm{~h} \text { of vendor- } \\
\text { provided education for } \\
\text { amyloid PET if applicable }\end{array}$ & $\begin{array}{l}\text { Direct participation } \\
\text { in minimum of } 40 \text { brain } \\
{ }^{18} \mathrm{~F}-\mathrm{FDG} \text { PET/MR imaging } \\
\text { examinations, or } 40 \text { brain } \\
{ }^{18} \mathrm{~F}-\mathrm{FDG} \text { PET examinations } \\
\text { plus } 40 \text { brain MR imaging } \\
\text { examinations; } 20 \text { amyloid } \\
\text { PET examinations if } \\
\text { applicable }\end{array}$ & $\begin{array}{l}\text { Minimum of } 6 \mathrm{~h} \text { of } \mathrm{CME} \text { in } \\
\text { brain }{ }^{18} \mathrm{~F}-\mathrm{FDG} \mathrm{PET} / \mathrm{MR} \\
\text { imaging, brain }{ }^{18} \mathrm{~F}-\mathrm{FDG} \\
\text { PET, or brain MR } \\
\text { imaging; } 3 \mathrm{~h} \text { of amyloid } \\
\text { PET if applicable }\end{array}$ \\
\hline & $\begin{array}{l}300 \text { brain MR imaging } \\
\text { examinations }\end{array}$ & MR imaging: $100 \mathrm{~h}$ & & \\
\hline \multirow{2}{*}{$\begin{array}{l}\text { DR or NM } \\
\text { residency } \\
\text { accredited by } \\
\text { ACGME, } \\
\text { RCPSC, Collège } \\
\text { des Médecins } \\
\text { du Québec or } \\
\text { AOA, without } \\
\text { board cer- } \\
\text { tification and } \\
\text { more than } 2 \text { y } \\
\text { since completing } \\
\text { residency/ } \\
\text { fellowship }\end{array}$} & $\begin{array}{l}50 \text { brain }{ }^{18} \mathrm{~F}-\mathrm{FDG} \text { PET } \\
\text { examinations; vendor- } \\
\text { provided training for } \\
\text { amyloid PET } \\
\text { examinations if } \\
\text { applicable }\end{array}$ & $\begin{array}{l}\text { PET: } 50 \mathrm{~h} ; 3 \mathrm{~h} \text { of vendor- } \\
\text { provided education for amyloid } \\
\text { PET if applicable }\end{array}$ & $\begin{array}{l}\text { Direct participation } \\
\text { in minimum of } 60 \text { brain } \\
{ }^{18} \mathrm{~F}-\mathrm{FDG} \text { PET/MR imaging } \\
\text { examinations, or } 60 \text { brain } \\
{ }^{18} \mathrm{~F}-\mathrm{FDG} \text { PET plus } 60 \text { brain } \\
\text { MR imaging examinations; } \\
30 \text { amyloid PET exam- } \\
\text { inations if applicable }\end{array}$ & $\begin{array}{l}\text { Minimum of } 15 \mathrm{~h} \text { of } \mathrm{CME} \text { in } \\
\text { brain }{ }^{18} \mathrm{~F}-\mathrm{FDG} \text { PET/MR } \\
\text { imaging, brain }{ }^{18} \mathrm{~F}-\mathrm{FDG} \\
\text { PET, or brain MR } \\
\text { imaging; } 3 \mathrm{~h} \text { of amyloid } \\
\text { PET if applicable }\end{array}$ \\
\hline & $\begin{array}{l}500 \text { brain MR imaging } \\
\text { examinations }\end{array}$ & MR imaging: $250 \mathrm{~h}$ & & \\
\hline \multirow[t]{2}{*}{$\begin{array}{l}\text { ABMS or } \\
\text { Canadian- } \\
\text { equivalent } \\
\text { board } \\
\text { certification in } \\
\text { another medical } \\
\text { specialty }\end{array}$} & $\begin{array}{l}100 \text { brain }{ }^{18} \mathrm{~F}-\mathrm{FDG} \text { PET } \\
\text { examinations; vendor- } \\
\text { provided training for } \\
\text { amyloid PET } \\
\text { examinations if } \\
\text { applicable }\end{array}$ & $\begin{array}{l}\text { PET: } 500 \mathrm{~h} \text { plus } 200 \mathrm{~h} \text { in radiation } \\
\text { physics/instrumentation/ } \\
\text { radiochemistry/ } \\
\text { radiopharmacology/radiation } \\
\text { dosimetry/radiation biology/ } \\
\text { radiation safety and protection/ } \\
\text { quality control/artifacts plus } \\
1,000 \mathrm{~h} \text { in clinical } \mathrm{NM} \text {, including } \\
\text { dosages, image evaluation, } \\
\text { correlation with other imaging, } \\
\text { interpretation; } 3 \mathrm{~h} \text { of vendor- } \\
\text { provided education for amyloid } \\
\text { PET if applicable }\end{array}$ & $\begin{array}{l}\text { Direct participation } \\
\text { in minimum of } 100 \text { brain } \\
{ }^{18} \mathrm{~F}-\mathrm{FDG} \text { PET/MR imaging } \\
\text { examinations, or } 100 \text { brain } \\
{ }^{18} \mathrm{~F}-\mathrm{FDG} \text { PET plus } 100 \text { brain } \\
\text { MR imaging examinations; } \\
30 \text { amyloid PET } \\
\text { examinations if applicable }\end{array}$ & $\begin{array}{l}\text { Minimum of } 30 \mathrm{~h} \text { of } \mathrm{CME} \text { in } \\
\text { brain }{ }^{18} \mathrm{~F}-\mathrm{FDG} \text { PET/MR } \\
\text { imaging, brain }{ }^{18} \mathrm{~F}-\mathrm{FDG} \\
\mathrm{PET} \text {, or brain MR } \\
\text { imaging; } 3 \mathrm{~h} \text { of amyloid } \\
\text { PET if applicable }\end{array}$ \\
\hline & $\begin{array}{l}750 \text { brain MR imaging } \\
\text { examinations }\end{array}$ & $\begin{array}{l}\text { MR imaging: } 500 \mathrm{~h} \text { plus } 200 \mathrm{~h} \\
\text { in MR imaging physics/ } \\
\text { instrumentation/chemistry/ } \\
\text { contrast agents/contrast use/ } \\
\text { imaging techniques/MR safety/ } \\
\text { quality control/artifacts/clinical } \\
\text { application/interpretation }\end{array}$ & & \\
\hline
\end{tabular}

ABR-DR = American Board of Radiology-Diagnostic Radiology; ABR-DR-NR = American Board of Radiology-Diagnostic Radiology plus Nuclear Radiology; CAQ = Certificate of Added Qualification (ABR Subspecialty Certificate); ABNM = American Board of Nuclear Medicine; AOBR = American Osteopathic Board of Radiology; RCPSC = Royal College of Physicians and Surgeons of Canada; NM = nuclear medicine; $A C G M E=$ Accreditation Council for Graduate Medical Education; AOA = American Osteopathic Association, ABMS = American Board of Medical Specialties; CME = continuing medical education. 
Jonathan McConathy, Carolyn C. Meltzer, and M. Elizabeth Oates. Hossein Jadvar and Rathan M. Subramaniam are cochairs.

\section{REFERENCES}

1. Judenhofer MS, Wehrl HF, Newport DF, et al. Simultaneous PET-MRI: a new approach for functional and morphological imaging. Nat Med. 2008;14:459-465.

2. Catana C, Drzezga A, Heiss WD, et al. PET/MRI for neurologic applications. J Nucl Med. 2012;53:1916-1925.

3. Jadvar H, Colletti PM. Competitive advantage of PET/MRI. Eur J Radiol. 2014;83:84-94.

4. Bohnen NI, Djang DS, Herholz K, et al. Effectiveness and safety of ${ }^{18} \mathrm{~F}-\mathrm{FDG}$ PET in the evaluation of dementia: a review of the recent literature. J Nucl Med. 2012;53:59-71.

5. Rowe CC, Villemagne VL. Brain amyloid imaging. J Nucl Med. 2011;52:17331740 .

6. ACR practice parameter for performing and interpreting magnetic resonance imaging (MRI). American College of Radiology website. http://www.acr.org/ /media/EB54F56780AC4C6994B77078AA1D6612.pdf. Published 1992. Last amended 2014. Accessed February 9, 2015.
7. ACR-SPR practice parameter for performing FDG-PET/CT in oncology. American College of Radiology website. http://www.acr.org/ /media/71B746780F934F6D8A1 BA5CCA5167EDB.pdf. Published 2007. Last amended 2014. Accessed February 9,2015

8. Conjoint statement of the SNM and the ACNP on credentialing and delineation of privileges for body PET. J Nucl Med. 2006;47:1559-1560.

9. Varrone A, Asenbaum S, Vander Borght T, et al. EANM procedure guidelines for PET brain imaging using $\left[{ }^{18} \mathrm{~F}\right] \mathrm{FDG}$, version 2. Eur J Nucl Med Mol Imaging. 2009;36:2103-2110.

10. ACR PET accreditation program requirements. http://www.acr.org/ /media/ ACR/Documents/Accreditation/Nuclear\%20Medicine\%20PET/PETRequire ments.pdf. American College of Radiology website. Published September 10, 2014. Accessed February 9, 2015.

11. ACR MRI accreditation program requirements. http://www.acr.org/ / media/ACR/Documents/Accreditation/MRI/Requirements.pdf. American College of Radiology website. Published July 2, 2014. Accessed February 9, 2015 .

12. Industry-sponsored training for amyloid brain PET. www.amyvidhcp.com/Pages/ reader-training.aspx. Accessed February 9, 2015

13. Industry-sponsored training for amyloid brain PET. www.readvizamyl.com. Accessed February 9, 2015. 